\title{
Evaluation of Phytoavailability of Heavy Metals to Chinese Cabbage (Brassica chinensis L.) in Rural Soils
}

\author{
Yao-Tsung Chang, ${ }^{1}$ Zeng-Yei Hseu, ${ }^{1}$ and Franz Zehetner ${ }^{2}$ \\ ${ }^{1}$ Department of Environmental Science and Engineering, National Pingtung University of Science and Technology, \\ Pingtung 91201, Taiwan \\ ${ }^{2}$ Institute of Soil Research, University of Natural Resources and Life Sciences, 1190 Vienna, Austria \\ Correspondence should be addressed to Zeng-Yei Hseu; zyhseu@mail.npust.edu.tw
}

Received 24 June 2014; Accepted 17 August 2014; Published 11 September 2014

Academic Editor: Christophe Waterlot

Copyright (C) 2014 Yao-Tsung Chang et al. This is an open access article distributed under the Creative Commons Attribution License, which permits unrestricted use, distribution, and reproduction in any medium, provided the original work is properly cited.

\begin{abstract}
This study compared the extractability of $\mathrm{Cd}, \mathrm{Cu}, \mathrm{Ni}, \mathrm{Pb}$, and $\mathrm{Zn}$ by 8 extraction protocols for 22 representative rural soils in Taiwan and correlated the extractable amounts of the metals with their uptake by Chinese cabbage for developing an empirical model to predict metal phytoavailability based on soil properties. Chemical agents in these protocols included dilute acids, neutral salts, and chelating agents, in addition to water and the Rhizon soil solution sampler. The highest concentrations of extractable metals were observed in the $\mathrm{HCl}$ extraction and the lowest in the Rhizon sampling method. The linear correlation coefficients between extractable metals in soil pools and metals in shoots were higher than those in roots. Correlations between extractable metal concentrations and soil properties were variable; soil $\mathrm{pH}$, clay content, total metal content, and extractable metal concentration were considered together to simulate their combined effects on crop uptake by an empirical model. This combination improved the correlations to different extents for different extraction methods, particularly for $\mathrm{Pb}$, for which the extractable amounts with any extraction protocol did not correlate with crop uptake by simple correlation analysis.
\end{abstract}

\section{Introduction}

Bioavailability of heavy metals in soils is critically dependent on the chemical speciation of the metals [1]. Plants respond only to the fraction that is "phytoavailable" to them. The readily soluble fraction of heavy metals is generally considered to be phytoavailable, but there is growing awareness that the current methods for assessment of "soluble" and "phytoavailable" fractions need reevaluation due to these fractions variability in both space and time [2]. The accurate estimation of heavy metal phytoavailability in soils is becoming more important as risk assessment and remediation efforts acknowledge that total metal concentrations may not be the best predictors of metal phytoavailability [3]. The most widely used methods for evaluating the phytoavailability of heavy metals in soils are single extraction and sequential extraction methods [4]. However, the sequential extraction methods are rather laborious and time consuming. Among single extraction methods, neutral salts, dilute acids, and chelating agents-all with only limited/varying successhave been the most widely used extractants besides resinbased techniques [5].

Water-soluble metal ions can be easily mobilized and may be considered as highly phytoavailable. To assess the readily bioavailable metal fractions under field conditions, collection and analysis of pore water have become an important aspect of environmental monitoring programs $[4,6,7]$. Understanding and modelling soil solution concentrations of heavy metals are indeed important in environmental assessment [8]. In this context, soil water extraction has the benefit of ascertaining metal concentrations at pseudoequilibrium in the soil solution. However, heavy metals can be adsorbed to negatively charged soil constituents, which are subject to cation exchange reactions, and can readily replenish soil solution levels. Weakly adsorbed metals are considered to be labile and available for plant uptake [3]. A wide variety of extractants have been proposed to ascertain metal exchangeability. Novozamsky et al. [9] proposed the use of 
$0.01 \mathrm{M} \mathrm{CaCl}_{2}$ as an extraction agent to estimate bioavailability of metals and nutrients in air-dried soil samples. However, Pueyo et al. [10] found systematically lower levels of extracted $\mathrm{Cd}, \mathrm{Cu}, \mathrm{Pb}$, and $\mathrm{Zn}$ when using $0.1 \mathrm{M} \mathrm{NaNO}_{3}$ compared to $1 \mathrm{M} \mathrm{NH}_{4} \mathrm{NO}_{3}$ or $0.01 \mathrm{M} \mathrm{CaCl}_{2}$. In addition to single extractions, the application of sequential extraction, as proposed by Tessier et al. [11], provides estimates of the possible mobility and bioavailability of heavy metals in soil and sediment environments. Several sequential extraction methods have been employed to partition metals into fractions defined as soluble, exchangeable, organically bound, precipitated, oxide bound, and residual and to correlate metals in these fractions with plant concentrations or uptake [12-14]. Extraction with $0.11 \mathrm{M}$ acetic acid (HOAc) is the first step of a three-step extraction procedure that was developed according to the Standards, Measurements, and Testing Program (formerly the European Community Bureau of Reference, generally termed the BCR method) [14]. The acidity of the HOAc induces dissolution of hydroxides and carbonates and increases overall metal solubility, whereas acetate induces additional metal mobilization by acting as a complexing agent. The use of HOAc can be of particular interest in bioavailability research because it is one of the most abundant low molecular weight organic acids (LMWOAs) present in the rhizosphere of many plants [15]. Baker and Amacher [16] defined the $0.1 \mathrm{M} \mathrm{HCl}$-extractable fraction as the metals operationally released by moderate acid attack from soils. Additionally, complex extraction solutions, aimed at mimicking rhizosphere effects in the soil, have been developed to ascertain bioavailability of trace metals. Lindsay and Norvell [17] proposed a diethylenetriaminepentaacetic acid- (DTPA-) based extraction solution, buffered at $\mathrm{pH} 7.3$ to exclude effects involving carbonate dissolution. This protocol is also widely used and predominant for phytoavailability studies. Also, ethylenediaminetetraacetic acid (EDTA) is often considered to provide a good estimate of the available soil metal concentrations $[4,18]$.

The soluble concentration of heavy metals in the soil solution is a poor indicator of phytoavailability because a portion of exchangeable as well as slightly complexed metals also contributes to the labile pool which can be easily taken up by roots $[3,4,6,18]$. In addition, there is increasing evidence that plants can alter the chemical mobility and phytoavailability of heavy metals in the rhizosphere [19-21]. The rhizosphere $\mathrm{pH}$ is often more acidic than that of the bulk soil, and thus larger amounts of heavy metals are dissolved and possibly taken up in the vicinity of the root. Roots can also release soluble LMWOAs into the rhizosphere which are capable of complexing heavy metals and, hence, increase their potential uptake by plants [19]. With respect to these processes that are governed by the plants, bioassays conducted with popular crops certainly provide the best approach for evaluating heavy metal phytoavailability. Various indicators of the phytoavailability of the metals can be derived from such tests, with the most often used being the crop uptake of heavy metal, as estimated by analyzing the metal content of the crop $[4,6,8,22,23]$. The aims of this study were (1) to explore the extractability of heavy metals $(\mathrm{Cd}, \mathrm{Cu}, \mathrm{Ni}, \mathrm{Pb}$, and $\mathrm{Zn}$ ) by different single extractions in rural soils varying in their degree of contamination, (2) to correlate the extractable concentrations of the metals with their uptake by a popular vegetable crop (Chinese cabbage), and (3) to develop an empirical model to predict the metal phytoavailability based on soil properties.

\section{Materials and Methods}

2.1. Soil Sample Collection. This study selected 22 surface soils $(0-15 \mathrm{~cm})$ to represent the major rural soils throughout Taiwan. These soils, derived from various parent materials, included a wide range of physical and chemical properties and degrees of heavy metal contamination. Entisols, Inceptisols, Andisols, Vertisols, Alfisols, Ultisols, and Oxisols (US soil classification system) were included in this study (Table 1). Their textures ranged from sandy loam to clay, and they differed in land use and agricultural production. Three of the soils contained elevated levels of $\mathrm{Cd}, \mathrm{Cu}, \mathrm{Ni}, \mathrm{Pb}$, or $\mathrm{Zn}$ due to illegal industrial wastewater discharge or hazardous solid waste disposal. Soil A from quaternary aged alluvium had been spiked with $\mathrm{Cd}$ and $\mathrm{Pb}$ salt for $1 \mathrm{yr}$ prior to this study. Soil $\mathrm{K}$ derived from serpentine in eastern Taiwan contained high amounts of endogenous $\mathrm{Cr}$ and $\mathrm{Ni}$ from the parent material. Soil F was moderately contaminated by industrial wastewater. The remaining 16 soils were uncontaminated reference soils. All the soils were air-dried, ground, and passed through a $2 \mathrm{~mm}$ sieve for laboratory analyses.

2.2. Characterization of the Studied Soils. The $\mathrm{pH}$ was measured using a mixture of soil and deionized water $(1: 1, \mathrm{w} / \mathrm{v})$ with a glass electrode [24]. Total organic carbon (OC) content was determined via the Walkley-Black wet oxidation method [25]. Cation exchange capacity (CEC) was determined with the ammonium acetate method $(\mathrm{pH}$ 7.0) [26]. Electrical conductivity (EC) was measured from the extract of a saturated paste of soil [27]. Total secondary free $\mathrm{Fe}\left(\mathrm{Fe}_{\mathrm{d}}\right)$ was extracted with the dithionite-citrate-bicarbonate method [28]. An acid ammonium oxalate ( $\mathrm{pH} 3.0$ ) extraction was performed for noncrystalline (amorphous) Fe oxides [29]. Finally, soil particle-size distribution was determined with the pipette method [30]. Total contents of $\mathrm{Cd}, \mathrm{Cu}, \mathrm{Ni}, \mathrm{Pb}$, and $\mathrm{Zn}$ were measured after aqua regia digestion, following the procedure recommended by the International Organization for Standardization [31]. Samples were digested at room temperature with $37 \% \mathrm{HCl} / 70 \% \mathrm{HNO}_{3}(3: 1)$ mixture $(28 \mathrm{~mL}$ per $3 \mathrm{~g}$ of sample) for $16 \mathrm{~h}$. After this, the suspension was digested at $130^{\circ} \mathrm{C}$ for $2 \mathrm{~h}$ under reflux conditions. The suspension was then filtered and diluted to $100 \mathrm{~mL}$ with $\mathrm{HNO}_{3} 0.5 \mathrm{~mol} \mathrm{~L}{ }^{-1}$ for analysis. Metal contents in all solutions were determined with a flame atomic absorption spectrophotometer (FAAS) (Hitachi Z-8100, Tokyo, Japan).

2.3. Single Extractions of Soil Heavy Metals. Six single extractions were undertaken to predict the labile pools of heavy metals in the soils (Table 2). The chemical extractants were distilled water, $\mathrm{NaNO}_{3}, \mathrm{CaCl}_{2}, \mathrm{HOAc}, \mathrm{HCl}, \mathrm{EDTA}$, and DTPA. All extracts were centrifuged and further filtered by a Whatman No. 42 filter paper and $<0.45 \mu \mathrm{m}$ Millipore filter 
TABLE 1: Description of the studied soils.

\begin{tabular}{|c|c|c|c|c|c|}
\hline $\begin{array}{l}\text { Soil } \\
\text { code }\end{array}$ & Classification & Texture & Parent materials & Land use & $\begin{array}{l}\text { Contamination with heavy } \\
\text { metal }\end{array}$ \\
\hline A & Typic Hapludox & Clay & Quaternary aged alluvium & Tropical orchard & Spiked $\mathrm{Cd}$ and $\mathrm{Pb}$ for $1 \mathrm{yr}$ \\
\hline $\mathrm{B}$ & Typic Paleudult & Sandy clay loam & Quaternary aged alluvium & Grass & Low \\
\hline $\mathrm{C}$ & Typic Melanudand & Silty clay loam & Volcanic ash & Secondary tropical forest & Low \\
\hline $\mathrm{D}$ & Typic Hapludult & Clay loam & Quaternary aged alluvium & Sugarcane & Low \\
\hline $\mathrm{E}$ & Typic Udorthent & Sandy clay loam & Andesite and limestone & Grass & Low \\
\hline $\mathrm{F}$ & Typic Fluvaquent & Silty clay loam & Slate alluvium & Lowland rice & Moderate \\
\hline G & Typic Paleudalf & Silty clay loam & Slate alluvium & Soybean & Low \\
\hline $\mathrm{H}$ & Typic Eutrudept & Silty clay loam & Slate alluvium & Lowland rice & High \\
\hline I & Typic Paleudalf & Clay loam & Sandstone and shale alluvium & Sugarcane & Low \\
\hline $\mathrm{J}$ & Typic Paleudalf & Loam & Coral reef and sandstone mixture & Virgin tropical forest & Low \\
\hline $\mathrm{K}$ & Typic Hapludert & Clay loam & Serpentine & Secondary tropical forest & Endogenous $\mathrm{Cr}$ and $\mathrm{Ni}$ \\
\hline $\mathrm{L}$ & Typic Eutrudept & Silty clay loam & Slate alluvium & Vineyard & Low \\
\hline M & Typic Udorthent & Loam & Slate alluvium & Corn & Low \\
\hline $\mathrm{N}$ & Lithic Udipsamment & Loam & Slate alluvium & Sugarcane & Low \\
\hline $\mathrm{O}$ & Typic Eutrudept & Silty clay loam & Slate and sandstone alluvium & Tropical orchard & Low \\
\hline $\mathrm{P}$ & Typic Udorthents & Sandy clay loam & Slate alluvium & Melon & Low \\
\hline Q & Lithic Udorthent & Sandy loam & Schist alluvium & Sugarcane & Low \\
\hline $\mathrm{R}$ & Typic Udorthents & Sandy loam & Sandstone and shale alluvium & Vegetable & Low \\
\hline $\mathrm{S}$ & Typic Hapludalf & Clay loam & Coral reef & Secondary tropical forest & Low \\
\hline $\mathrm{T}$ & Lithic Udipsamment & Sandy loam & Slate alluvium & Fallow & High \\
\hline $\mathrm{U}$ & Typic Urothent & Silt loam & Slate alluvium & Fallow & High \\
\hline $\mathrm{V}$ & Typic Urothent & Clay loam & Mudstone & Soybean & Low \\
\hline
\end{tabular}

TABLE 2: Single extraction procedures used.

\begin{tabular}{lccc}
\hline Extraction method & Liquid : solid ratio & Equilibration time & Reference \\
\hline Rhizon soil solution samplers & At field capacity & 40-day incubation & Mench et al. [34] \\
Distilled water & $5: 1$ & $16 \mathrm{~h}$ & Gupta and Aten [35] \\
$0.1 \mathrm{M} \mathrm{NaNO}_{3}$ & $5: 2$ & $2 \mathrm{~h}$ & Novozamsky et al. [9] \\
$0.01 \mathrm{M} \mathrm{CaCl}_{2}$ & $10: 1$ & $3 \mathrm{~h}$ & Ure et al. [36] \\
$0.11 \mathrm{M} \mathrm{HOAc}$ & $20: 1$ & $16 \mathrm{~h}$ & $1 \mathrm{~h}$ \\
$0.1 \mathrm{~N} \mathrm{HCl}$ & $10: 1$ & $1 \mathrm{~h}$ & Baker and Amacher [16] \\
$0.05 \mathrm{M} \mathrm{EDTA}$ & $10: 1$ & $2 \mathrm{~h}$ & Wear and Evans [37] \\
$0.005 \mathrm{M} \mathrm{DTPA}, 0.01 \mathrm{M} \mathrm{CaCl}_{2}$, and $0.1 \mathrm{M} \mathrm{TEA}$ & $2: 1$ & Lindsay and Norvell [17] \\
\hline
\end{tabular}

paper. The metal concentrations in all the above solutions were determined by FAAS or ICP-OES (Optima 2100DV Model, Perkin-Elmer, USA). All soil samples were extracted and analyzed in triplicate. Additionally, Rhizon soil solution sampling was used (further described in the next section).

2.4. Pot Experiment of Chinese Cabbage. Air-dried soil (2 kg) was weighed and transferred into a plastic pot $10 \mathrm{~cm}$ in diameter. Chinese cabbage (Brassica chinensis L.) is a popular foliar crop in Taiwan. Seeds of Chinese cabbage were incubated at $25^{\circ} \mathrm{C}$ on filter papers in Petri dishes containing $10 \mathrm{~mL}$ distilled water for 5 days. Five germinated seeds were planted at a depth of $0.5 \mathrm{~cm}$ in the soil in each pot, which was fertilized with $50 \mathrm{mg} \mathrm{N} \mathrm{kg}^{-1}$ ammonium sulfate, $50 \mathrm{mg} \mathrm{P} \mathrm{kg}^{-1}$ calcium phosphate, and $40 \mathrm{mg} \mathrm{K} \mathrm{kg}^{-1}$ potassium chloride, in a greenhouse. Greenhouse relative humidity was 70-90\%, air temperature was $23-27^{\circ} \mathrm{C}$, and day length was approximately $12 \mathrm{~h}$. After 1 week, the seedlings were thinned to 1 per pot. The soil moisture content was adjusted daily to $75 \%$ of its water holding capacity by weighing the pots and adding deionized water to compensate for weight loss. The pot bottoms were sealed to eliminate leaching of mobilized heavy metals. This experiment was performed for all 22 soils in triplicate in a random block design; thus, 66 pots were used. The plant shoots, cut at the soil surface, were harvested 40 days after the seedling thinning. The soil was then broken up and roots were harvested by hand. The roots were washed in tap water 
TABLE 3: Selected properties of the studied soils.

\begin{tabular}{|c|c|c|c|c|c|c|c|}
\hline Soil code & $\mathrm{pH}$ & $\begin{array}{c}\mathrm{OC}^{\mathrm{a}} \\
\%\end{array}$ & $\begin{array}{c}\mathrm{CEC}^{\mathrm{b}} \\
\mathrm{Cmol} \mathrm{kg}^{-1}\end{array}$ & $\begin{array}{c}\mathrm{EC}^{\mathrm{c}} \\
\mathrm{dS} \mathrm{m}^{-1}\end{array}$ & $\mathrm{Fe}_{\mathrm{o}}{ }^{\mathrm{d}}$ & $\mathrm{Fe}_{\mathrm{d}}{ }^{\mathrm{e}}$ & $\begin{array}{c}\text { Clay } \\
\%\end{array}$ \\
\hline A & 4.1 & 1.3 & 3.9 & 0.20 & 4.47 & 19.4 & 47 \\
\hline B & 4.5 & 0.8 & 10 & 0.19 & 0.50 & 6.7 & 28 \\
\hline $\mathrm{C}$ & 4.5 & 17 & 50 & 0.31 & 2.51 & 18.6 & 34 \\
\hline $\mathrm{D}$ & 4.8 & 2.1 & 9.9 & 0.26 & 3.66 & 7.11 & 33 \\
\hline $\mathrm{E}$ & 5.3 & 4.2 & 3.5 & 0.21 & 1.40 & 1.54 & 18 \\
\hline $\mathrm{F}$ & 5.6 & 3.1 & 5.0 & 0.82 & 6.95 & 8.37 & 37 \\
\hline G & 5.6 & 4.3 & 13 & 1.30 & 2.44 & 8.49 & 27 \\
\hline $\mathrm{H}$ & 6.1 & 3.8 & 17 & 0.51 & 8.62 & 9.29 & 38 \\
\hline I & 6.1 & 1.5 & 9.9 & 0.66 & 2.89 & 6.60 & 29 \\
\hline$J$ & 6.4 & 1.9 & 7.8 & 2.58 & 1.08 & 14.4 & 25 \\
\hline K & 6.5 & 2.9 & 32 & 0.32 & 0.83 & 14.0 & 36 \\
\hline $\mathrm{L}$ & 7.0 & 1.4 & 9.7 & 2.54 & 2.35 & 5.43 & 31 \\
\hline M & 7.0 & 1.5 & 7.7 & 1.08 & 1.62 & 6.27 & 24 \\
\hline $\mathrm{N}$ & 7.1 & 0.8 & 8.5 & 1.40 & 2.21 & 7.07 & 19 \\
\hline $\mathrm{O}$ & 7.3 & 1.6 & 8.3 & 1.06 & 2.70 & 9.23 & 30 \\
\hline $\mathrm{P}$ & 7.5 & 0.3 & 8.9 & 1.42 & 0.97 & 14.0 & 18 \\
\hline Q & 7.6 & 2.3 & 4.4 & 0.87 & 1.40 & 2.25 & 10 \\
\hline $\mathrm{R}$ & 7.7 & 1.3 & 5.9 & 0.37 & 1.68 & 6.27 & 18 \\
\hline S & 7.8 & 1.6 & 9.6 & 0.42 & 0.75 & 6.80 & 29 \\
\hline $\mathrm{T}$ & 8.1 & 1.1 & 4.4 & 0.53 & 3.37 & 3.98 & 15 \\
\hline $\mathrm{U}$ & 8.2 & 1.6 & 3.9 & 16.5 & 2.19 & 6.53 & 20 \\
\hline $\mathrm{V}$ & 8.8 & 0.6 & 8.5 & 10.7 & 2.26 & 1.98 & 30 \\
\hline
\end{tabular}

${ }^{\mathrm{a}}$ Organic carbon.

${ }^{\mathrm{b}}$ Cation exchange capacity.

${ }^{\mathrm{c}}$ Electrical conductivity.

${ }^{\mathrm{d}}$ Oxalate extractable iron.

${ }^{\mathrm{e}}$ Dithionite-citrate-bicarbonate extractable iron.

until free of soil particles. The shoots and roots were further washed with deionized water, oven-dried at $70^{\circ} \mathrm{C}$ for $24 \mathrm{~h}$, weighed, and then ground and passed through a $1.0 \mathrm{~mm}$ sieve. Aliquots of plant powder ( $0.5 \mathrm{~g}$ dried weight) were digested overnight in $14 \mathrm{M} \mathrm{HNO}_{3}(5 \mathrm{~mL})$ and $30 \% \mathrm{H}_{2} \mathrm{O}_{2} \mathrm{v} / \mathrm{v}(10 \mathrm{~mL})$ and heated at $120^{\circ} \mathrm{C}$ for $2 \mathrm{~h} \mathrm{[32].} \mathrm{The} \mathrm{digested} \mathrm{solutions} \mathrm{were}$ filtered using Whatman No. 42 filter paper and diluted to $50 \mathrm{~mL}$ with deionized water. The concentrations of heavy metals in the digested solution were determined by ICPOES. Additionally, the Rhizon soil solution sampler (2 $\mathrm{mm}$ in diameter) with no ion exchange capacity (RSMS: rhizosphere research product, Eijkelkamp, Giesbeek, The Netherlands) was inserted vertically in the center of each pot. Soil solution samples were collected by suction using a syringe at plant harvest (day 40). The metals in these solutions were directly analyzed by ICP-OES.

2.5. Quality Assurance, Quality Control, and Statistical Analysis. Two standard reference materials, BCR-141R (loam soil) and SRM 1573a (tomato leaves), were digested in triplicate and analyzed using aqua regia and the plant digestion method described. A good agreement was observed between the measured and the certified values for the metals analyzed $(\mathrm{Cd}, \mathrm{Cu}, \mathrm{Ni}, \mathrm{Pb}$, and $\mathrm{Zn})$, with recovery ranging from 85 to $110 \%$. A blank was run for each extraction procedure to correct the measurements. For sets of every ten samples, a procedure blank and spiked sample, involving all reagents, was performed to check for interference and cross contamination. The limit of detection, calculated as $3 \mathrm{~s} / \mathrm{m}$ (where $s$ is the standard deviation of the blank and $m$ is the slope of the calibration curve), for each element determined was $\left(\mathrm{mg} \mathrm{L}^{-1}\right.$ ) Cd, 0.005; Cu, 0.01; Ni, 0.02; Pb, 0.04; and $\mathrm{Zn}, 0.001$ for the FAAS measurements. However, the limit of detection for each element determined was $\left(\mu \mathrm{g} \mathrm{L}^{-1}\right) \mathrm{Cd}, 0.1 ; \mathrm{Cu}, 0.6$; $\mathrm{Ni}, 0.01 ; \mathrm{Pb}, 2.0$; and $\mathrm{Zn}, 0.1$ for the ICP-OES measurements. Descriptive statistics, Pearson correlations, and significance analysis $(P=0.01 ; 0.05)$ were performed using SPSS 11.0 (SPSS Inc.) and Excel (Microsoft Inc.) software packages.

\section{Results and Discussion}

3.1. Soil Characteristics and Total Metals. The soils used for this study varied widely in their properties (Table 3 ). Soil $\mathrm{pH}$ values ranged from 4.1 to 8.8 , while soils $\mathrm{A}, \mathrm{B}, \mathrm{C}, \mathrm{D}$, and $\mathrm{E}$ were strongly acidic, soils Q, R, S, T, U, and V were strongly alkaline, and the others tended to be neutral. All soils were characterized by low and medium organic carbon contents (ranging from 0.3 to $4.3 \%$ ), typical for humid tropical regions, 
TABLE 4: Total contents of heavy metals in the studied soils and the soil control standards (SCS) for rural lands in Taiwan.

\begin{tabular}{lccccc}
\hline Soil code & $\mathrm{Cd}$ & $\mathrm{Cu}$ & $\begin{array}{c}\mathrm{Ni} \\
\mathrm{mg} \mathrm{kg}^{-1}\end{array}$ & $\mathrm{~Pb}$ & $\mathrm{Zn}$ \\
\hline $\mathrm{A}$ & 18.9 & 18.4 & 21.0 & 965 & 47.8 \\
$\mathrm{~B}$ & 0.55 & 10.1 & 35.3 & 41.5 & 16.8 \\
$\mathrm{C}$ & 1.05 & 57.6 & 12.3 & 41.5 & 66.2 \\
$\mathrm{D}$ & 0.71 & 23.9 & 24.4 & 29.6 & 69.6 \\
$\mathrm{E}$ & 0.87 & 17.5 & 26.0 & 3.74 & 34.9 \\
$\mathrm{~F}$ & 0.91 & 16.4 & 53.1 & 25.8 & 39.4 \\
$\mathrm{G}$ & 0.74 & 30.5 & 44.1 & 25.8 & 67.8 \\
$\mathrm{H}$ & 1.57 & 475 & 407 & 36.6 & 607 \\
$\mathrm{I}$ & 0.74 & 12.1 & 19.7 & 17.1 & 72.4 \\
$\mathrm{~J}$ & 0.90 & 14.0 & 31.4 & 15.1 & 44.9 \\
$\mathrm{~K}$ & 0.46 & 46.8 & 2210 & 13.5 & 85.0 \\
$\mathrm{~L}$ & 1.25 & 38.3 & 30.2 & 21.6 & 153 \\
$\mathrm{M}$ & 1.05 & 23.9 & 33.3 & 20.5 & 104 \\
$\mathrm{~N}$ & 0.45 & 22.5 & 17.6 & 17.4 & 97.8 \\
$\mathrm{O}$ & 1.10 & 48.7 & 37.8 & 35.0 & 187 \\
$\mathrm{P}$ & 0.33 & 15.4 & 24.7 & 10.0 & 67.7 \\
$\mathrm{Q}$ & 1.34 & 18.7 & 18.5 & 15.1 & 39.1 \\
$\mathrm{R}$ & 1.02 & 9.60 & 20.8 & 14.4 & 52.8 \\
$\mathrm{~S}$ & 1.53 & 20.0 & 26.3 & 36.8 & 142 \\
$\mathrm{~T}$ & 3.60 & 1820 & 1170 & 2690 & 2740 \\
$\mathrm{U}$ & 6.25 & 2270 & 878 & 2100 & 998 \\
$\mathrm{~V}$ & 1.02 & 18.8 & 37.4 & 22.1 & 84.3 \\
\hline SCS & 5.00 & 200 & 200 & 500 & 600 \\
\hline & & & & &
\end{tabular}

except for soil C, which were derived from volcanic ash. Because of the wide range of soil texture, the CEC values varied from 3.5 to $50 \mathrm{cmol} \mathrm{kg}^{-1}$. The soils had medium to high clay contents ranging from 10 to $47 \%$. Comparing to the soil control standards (SCS) for rural lands in Taiwan, it became obvious that heavy contamination of $\mathrm{Cd}, \mathrm{Cu}, \mathrm{Ni}, \mathrm{Pb}$, and $\mathrm{Zn}$ occurred in several soils including soils $\mathrm{A}, \mathrm{H}, \mathrm{K}, \mathrm{T}$, and $\mathrm{U}$ (Table 4).

\subsection{Comparison of Extractable Metals Using Various Extrac-} tion Methods. Table 5 lists the ranges and means of metal concentrations obtained with different extraction methods. The metal concentrations collected by the 1:5 soil-water extract from the air-dried soils were higher than those by the Rhizon method with suction from the field-capacity soils. However, the amounts of metals brought into solution by water from a soil are usually very low, and thus the metal concentrations with water extraction and the Rhizon method were much lower than those with the other methods (Table 5). Of all the single extractions in this study, $\mathrm{HCl}$ was theoretically the most aggressive agent for removing metals from the soil, and thus $\mathrm{HCl}$-extractable metals were the highest. Generally, the extractable metals followed the descending order $\mathrm{HCl}>\mathrm{EDTA}>\mathrm{DTPA}>\mathrm{HOAc}>\mathrm{CaCl}_{2}>$ $\mathrm{NaNO}_{3}>\mathrm{H}_{2} \mathrm{O}>$ Rhizon method. In addition to $\mathrm{HCl}$, chelating agents EDTA and DTPA as well as HOAc extracted more metals from the soils than $\mathrm{CaCl}_{2}$ and $\mathrm{NaNO}_{3}$. The reasons for this extraction order are easily understood. EDTA is a strong and nonspecific chelating agent; it can extract labile and nonlabile fractions of metals in soil and has been reported to remove both organically bound metals and metals occluded in oxides and secondary clay minerals in part [13]. However, DTPA was originally developed for nearneutral and calcareous soils as it is buffered at $\mathrm{pH} 7.3$ and therefore minimizes dissolution of carbonates [17], although uncertainty concerning the dissolution of iron and aluminum compounds remains [13].

The $0.11 \mathrm{M}$ HOAc was used in the first step of the abovementioned BCR method. Acetic acid can extract organic matter-bound metals in part and release most of the metals associated with carbonates and minerals such as kaolinite and ferrihydrite [33]. On the other hand, with the soil background electrolyte solutions $\mathrm{CaCl}_{2}$ and $\mathrm{NaNO}_{3}$, easily exchangeable metals can be extracted [10]. However, lower concentrations of metals were generally extracted with $\mathrm{NaNO}_{3}$ than with $\mathrm{CaCl}_{2}$ because monovalent cations exert only weak competition for adsorption sites on organic matter [9].

3.3. Simple Correlation Analysis between Single Extractions and Plant Concentrations. The correlations between extractable metals from soil pools and plant metal concentrations were better for shoots than roots (Table 6). However, for $\mathrm{Cd}$ and $\mathrm{Pb}$, the correlations were low and mostly nonsignificant. For any of the studied metals, the concentrations in roots or shoots of Chinese cabbage were not significantly $(P<0.05)$ correlated with those in the Rhizon soil solution sampler, even though the Rhizon samplers were originally designed for seepage water sampling in the unsaturated zone [4]. This result suggests that the plants took up heavy metals from pools other than seepage water. The edible part of Chinese cabbage is the shoot, and the correlation coefficients between extractable metals in soil pools and metals in shoots were higher than in roots. Thus, the following discussion was focused on the relationship between $\mathrm{Cu}, \mathrm{Ni}$, and $\mathrm{Zn}$ in shoots and in soil pools. The concentrations of $\mathrm{Cu}, \mathrm{Ni}$, and $\mathrm{Zn}$ in the shoots of Chinese cabbage were significantly and positively correlated with the metals extracted by water, $\mathrm{NaNO}_{3}, \mathrm{CaCl}_{2}$, $\mathrm{HOAc}, \mathrm{HCl}$, EDTA, DTPA, and aqua regia, suggesting that these extraction procedures provided good measures for $\mathrm{Cu}$, $\mathrm{Ni}$, and $\mathrm{Zn}$ phytoavailability under the current experimental conditions. However, the correlations were always better for $\mathrm{Cu}$ and $\mathrm{Ni}$ compared to $\mathrm{Zn}$.

3.4. Soil Property Considerations of Single Extractions. Table 7 demonstrates the relationships between the metal concentration in the different extractable fractions and selected soil properties including $\mathrm{pH}, \mathrm{OC}, \mathrm{CEC}, \mathrm{EC}, \mathrm{Fe}_{\mathrm{o}} / \mathrm{Fe}_{\mathrm{d}}$, and clay content. These soil properties have previously been found to control the solubility and activity of heavy metals in soils and to affect metal phytoavailability [3]. The chemical extraction methods are based on the assumption that there is a relationship between the extractable fraction of metals and the phytoavailability of the metals to plants; a good correlation 


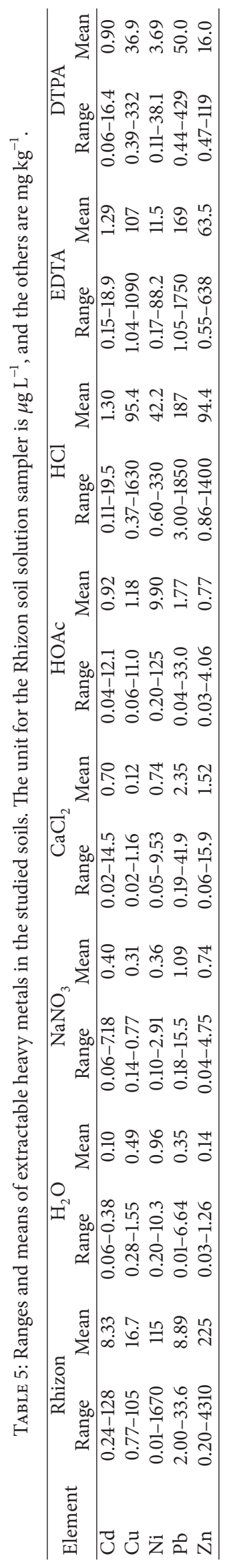


TABLE 6: Pearson linear correlation coefficients between heavy metal extracted from the soil with different extraction methods and concentrations in the root and shoot of Chinese cabbage ( $n=17$ for $\mathrm{Cd}$ and $\mathrm{Pb} ; n=18$ for $\mathrm{Cu}, \mathrm{Ni}$, and $\mathrm{Zn}$ ).

\begin{tabular}{|c|c|c|c|c|c|}
\hline & $\mathrm{Cd}$ & $\mathrm{Cu}$ & $\mathrm{Ni}$ & $\mathrm{Pb}$ & $\mathrm{Zn}$ \\
\hline \multicolumn{6}{|c|}{ Root } \\
\hline Rhizon & -0.19 & -0.25 & -0.05 & 0.05 & -0.12 \\
\hline $\mathrm{H}_{2} \mathrm{O}$ & -0.21 & $0.69^{* *}$ & $0.97^{* *}$ & -0.30 & 0.50 \\
\hline $\mathrm{NaNO}_{3}$ & 0.04 & $0.69^{* *}$ & 0.27 & -0.14 & 0.50 \\
\hline $\mathrm{CaCl}_{2}$ & -0.28 & $0.79^{* *}$ & 0.19 & -0.21 & $0.53^{*}$ \\
\hline HOAc & -0.09 & $0.71^{* *}$ & 0.21 & $0.55^{*}$ & 0.43 \\
\hline $\mathrm{HCl}$ & -0.30 & $0.68^{* *}$ & $0.56^{*}$ & 0.20 & 0.51 \\
\hline EDTA & -0.28 & $0.66^{* *}$ & $0.80^{* *}$ & -0.33 & $0.52^{*}$ \\
\hline DTPA & -0.24 & $0.67^{* *}$ & $0.64^{* *}$ & -0.20 & $0.54^{*}$ \\
\hline Aqua regia & -0.21 & $0.69^{* *}$ & $0.97^{* *}$ & -0.18 & 0.45 \\
\hline \multicolumn{6}{|c|}{ Shoot } \\
\hline Rhizon & -0.05 & -0.13 & -0.07 & -0.14 & -0.06 \\
\hline $\mathrm{H}_{2} \mathrm{O}$ & 0.06 & $0.89^{* *}$ & $0.72^{* *}$ & -0.06 & $0.65^{* *}$ \\
\hline $\mathrm{NaNO}_{3}$ & 0.31 & $0.69^{* *}$ & $0.80^{* *}$ & -0.37 & $0.74^{* *}$ \\
\hline $\mathrm{CaCl}_{2}$ & 0.14 & $0.93^{* *}$ & $0.75^{* *}$ & -0.40 & $0.73^{* *}$ \\
\hline HOAc & 0.04 & $0.90^{* *}$ & $0.75^{* *}$ & 0.27 & $0.75^{* *}$ \\
\hline $\mathrm{HCl}$ & -0.22 & $0.91^{* *}$ & $0.94^{* *}$ & 0.17 & $0.66^{* *}$ \\
\hline EDTA & -0.14 & $0.91^{* *}$ & $0.97^{* *}$ & 0.21 & $0.66^{* *}$ \\
\hline DTPA & -0.04 & $0.91^{* *}$ & $0.96^{* *}$ & -0.13 & $0.69^{* *}$ \\
\hline Aqua regia & 0.11 & $0.91^{* *}$ & $0.80^{* *}$ & 0.12 & $0.60^{* *}$ \\
\hline
\end{tabular}

${ }^{* *}$ Significant at the 0.01 level, ${ }^{*}$ significant at the 0.05 level.

is therefore supposed to reflect that the particular soil metal fraction is available to plants. However, a statistically significant correlation of the soil-to-plant system does not necessarily provide insight into the mechanisms of phytoavailability [20]. Different physical, chemical, and biological mechanisms may govern the translocation of different metals from soils to plants [3]. We observed highly variable correlations between extractable metal concentrations and soil properties (Table 7), which may reflect the different above-mentioned extraction mechanisms. Overall, $\mathrm{pH}$ and clay content were the most important soil properties affecting metal extractability, which is consistent with previous findings [3].

Considering this situation, a stepwise multiple linear regression analysis was performed. Soil $\mathrm{pH}$, clay content, total metal contents (by aqua regia) of soils, and extractable metal concentrations were considered to simulate their combined effects on plant metal uptake. An empirical model was derived to express the relationships between metal phytoavailability and soil properties as follows:

$$
\begin{aligned}
\operatorname{Metal}_{\text {shoot }}= & a+b \mathrm{Metal}_{\text {aqua regia }} \\
& +c \mathrm{Metal}_{\text {extraction }}+d \mathrm{pH}+e \text { Clay, }
\end{aligned}
$$

where Metal $_{\text {shoot }}$ and Metal $_{\text {aqua regia }}$ are the total metal concentrations in plant shoots and in soils, respectively. Metal $_{\text {extraction }}$ is the metal concentration in the extractable soil fractions. The data of $\mathrm{Cd}$ and $\mathrm{Pb}$ in soil $\mathrm{A}$ were excluded for running this model because highly spiked $\mathrm{Cd}$ and $\mathrm{Pb}$ levels caused a clear bias of the normality $t$-test. Additionally, Chinese cabbage could not be harvested in the soils T, U, and $\mathrm{V}$ because their $\mathrm{pH}$ was too high to cultivate the crop. Therefore, the $n$ value for $\mathrm{Cd}$ and $\mathrm{Pb}$ was 17 and that for $\mathrm{Cu}$, $\mathrm{Ni}$, and $\mathrm{Zn}$ is 18 for this model. For simplicity, the coefficients of the empirical equations are omitted. The coefficient of determination, $r^{2}$, allows an evaluation of the overall prediction of phytoavailability (Table 8). In general, the inclusion of soil property variables improved the correlations to different extents for different extraction methods, particularly for $\mathrm{Pb}$, for which the extractable amounts were not correlated with plant uptake by simple correlation analysis. Nevertheless, this model still performed poorly in predicting plant uptake of Cd.

\section{Summary and Conclusions}

The metal levels extracted with all the single extraction protocols employed in this study were much higher than those with the Rhizon soil solution sampler. The extractable metals followed the descending order $\mathrm{HCl}>$ EDTA $>$ DTPA $>\mathrm{HOAc}>\mathrm{CaCl}_{2}>\mathrm{NaNO}_{3}>\mathrm{H}_{2} \mathrm{O}>$ Rhizon method. Low correlation was observed between extractable $\mathrm{Cd}$ and $\mathrm{Pb}$ in the soils and their respective contents in the roots and shoots of Chinese cabbage. Because of the different extraction mechanisms utilized by the different methods, correlations between extractable heavy metals and soil properties were highly variable. However, $\mathrm{pH}$ and clay content were identified as the most important soil properties affecting metal extractability. Soil $\mathrm{pH}$, clay content, total metal contents of soils, and extractable metal concentrations were considered 
TABle 7: Pearson linear correlation coefficients between extractable heavy metal concentrations and soil properties $(n=22)$.

\begin{tabular}{|c|c|c|c|c|c|c|c|c|c|c|}
\hline \multirow[b]{2}{*}{ Extraction } & \multicolumn{5}{|c|}{$\mathrm{pH}$} & \multicolumn{5}{|c|}{ OC } \\
\hline & $\mathrm{Cd}$ & $\mathrm{Cu}$ & $\mathrm{Ni}$ & $\mathrm{Pb}$ & $\mathrm{Zn}$ & $\mathrm{Cd}$ & $\mathrm{Cu}$ & $\mathrm{Ni}$ & $\mathrm{Pb}$ & $\mathrm{Zn}$ \\
\hline Rhizon & $-0.43^{*}$ & 0.11 & -0.08 & -0.30 & -0.09 & -0.08 & -0.07 & -0.07 & -0.11 & -0.07 \\
\hline $\mathrm{H}_{2} \mathrm{O}$ & -0.24 & 0.21 & -0.01 & $-0.41^{*}$ & -0.19 & -0.20 & -0.02 & 0.05 & -0.08 & 0.01 \\
\hline $\mathrm{NaNO}_{3}$ & $-0.41^{*}$ & -0.35 & -0.11 & $-0.45^{*}$ & -0.27 & -0.08 & $0.53^{* *}$ & 0.12 & -0.06 & 0.34 \\
\hline $\mathrm{CaCl}_{2}$ & $-0.41^{*}$ & -0.26 & -0.06 & $-0.42^{*}$ & -0.14 & -0.08 & 0.18 & 0.06 & -0.07 & 0.16 \\
\hline HOAc & -0.37 & -0.20 & -0.32 & $-0.41^{*}$ & -0.38 & -0.11 & 0.13 & $0.93^{* *}$ & -0.08 & 0.31 \\
\hline $\mathrm{HCl}$ & -0.36 & 0.25 & 0.34 & 0.23 & 0.27 & -0.09 & -0.08 & -0.07 & -0.14 & -0.09 \\
\hline EDTA & -0.35 & 0.37 & 0.13 & 0.27 & 0.36 & -0.09 & -0.09 & 0.01 & -0.13 & -0.10 \\
\hline DTPA & -0.39 & 0.35 & -0.04 & -0.12 & 0.24 & -0.09 & -0.08 & 0.07 & -0.14 & -0.03 \\
\hline \multirow[t]{2}{*}{ Aqua regia } & -0.26 & 0.38 & 0.20 & 0.27 & 0.36 & -0.10 & -0.09 & -0.04 & -0.13 & -0.10 \\
\hline & \multicolumn{5}{|c|}{ CEC } & \multicolumn{5}{|c|}{$\mathrm{EC}$} \\
\hline Extraction & $\mathrm{Cd}$ & $\mathrm{Cu}$ & $\mathrm{Ni}$ & $\mathrm{Pb}$ & $\mathrm{Zn}$ & $\mathrm{Cd}$ & $\mathrm{Cu}$ & $\mathrm{Ni}$ & $\mathrm{Pb}$ & $\mathrm{Zn}$ \\
\hline Rhizon & -0.16 & -0.10 & -0.03 & -0.10 & -0.03 & -0.12 & 0.15 & -0.07 & -0.14 & -0.09 \\
\hline $\mathrm{H}_{2} \mathrm{O}$ & -0.22 & 0.01 & $0.47^{*}$ & -0.15 & 0.04 & -0.02 & 0.27 & -0.12 & -0.11 & -0.16 \\
\hline $\mathrm{NaNO}_{3}$ & -0.15 & 0.41 & 0.27 & -0.13 & 0.36 & -0.10 & 0.20 & -0.12 & -0.12 & 0.00 \\
\hline $\mathrm{CaCl}_{2}$ & -0.15 & 0.21 & 0.19 & -0.14 & 0.18 & -0.10 & -0.13 & -0.09 & -0.11 & -0.02 \\
\hline HOAC & -0.17 & 0.14 & $0.86^{* *}$ & -0.14 & 0.30 & -0.07 & -0.12 & -0.13 & -0.10 & -0.24 \\
\hline $\mathrm{HCl}$ & -0.17 & -0.11 & -0.04 & -0.25 & -0.12 & -0.07 & -0.10 & 0.50 & 0.37 & -0.04 \\
\hline EDTA & -0.17 & -0.17 & 0.32 & -0.23 & -0.16 & -0.02 & 0.43 & 0.01 & 0.39 & 0.34 \\
\hline DTPA & -0.16 & -0.15 & 0.37 & -0.24 & -0.07 & -0.07 & 0.55 & -0.11 & 0.00 & 0.36 \\
\hline \multirow[t]{2}{*}{ Aqua regia } & -0.21 & -0.17 & 0.29 & -0.24 & -0.16 & 0.13 & 0.59 & 0.15 & $0.41^{*}$ & 0.34 \\
\hline & \multicolumn{5}{|c|}{$\mathrm{Fe}_{\mathrm{o}} / \mathrm{Fe}_{\mathrm{d}}$} & \multicolumn{5}{|c|}{ Clay } \\
\hline Extraction & $\mathrm{Cd}$ & $\mathrm{Cu}$ & $\mathrm{Ni}$ & $\mathrm{Pb}$ & $\mathrm{Zn}$ & $\mathrm{Cd}$ & $\mathrm{Cu}$ & $\mathrm{Ni}$ & $\mathrm{Pb}$ & $\mathrm{Zn}$ \\
\hline Rhizon & -0.12 & 0.00 & -0.07 & -0.38 & 0.03 & $0.52^{* *}$ & -0.17 & 0.03 & 0.37 & 0.07 \\
\hline $\mathrm{H}_{2} \mathrm{O}$ & -0.11 & 0.32 & -0.20 & -0.12 & 0.36 & $0.44^{*}$ & 0.05 & 0.21 & $0.52^{* *}$ & 0.37 \\
\hline $\mathrm{NaNO}_{3}$ & -0.13 & 0.05 & 0.25 & -0.14 & 0.22 & $0.50^{* *}$ & 0.20 & 0.32 & $0.51^{* *}$ & 0.38 \\
\hline $\mathrm{CaCl}_{2}$ & -0.13 & 0.29 & 0.29 & -0.14 & 0.33 & $0.51^{* *}$ & $0.42^{*}$ & 0.30 & $0.51^{* *}$ & 0.32 \\
\hline HOAC & -0.18 & 0.37 & -0.10 & -0.12 & 0.30 & $0.48^{* *}$ & 0.31 & 0.26 & $0.51^{* *}$ & $0.46^{*}$ \\
\hline $\mathrm{HCl}$ & -0.09 & 0.37 & 0.22 & 0.16 & 0.36 & $0.47^{*}$ & -0.24 & -0.16 & -0.18 & -0.25 \\
\hline EDTA & -0.10 & 0.28 & 0.14 & 0.18 & 0.32 & $0.46^{*}$ & -0.29 & 0.16 & -0.22 & -0.27 \\
\hline DTPA & -0.12 & 0.27 & 0.13 & 0.07 & 0.37 & $0.50^{* *}$ & -0.22 & 0.35 & 0.19 & -0.05 \\
\hline Aqua regia & -0.07 & 0.20 & -0.04 & 0.16 & 0.32 & 0.40 & -0.29 & 0.04 & -0.21 & -0.27 \\
\hline
\end{tabular}

${ }^{* * *}$ Significant at the 0.01 level, ${ }^{*}$ significant at the 0.05 level.

TABLE 8: Coefficients of determination $\left(r^{2}\right)$ obtained by multiple linear regression $(n=17$ for $\mathrm{Cd}$ and $\mathrm{Pb} ; n=18$ for $\mathrm{Cu}, \mathrm{Ni}$, and $\mathrm{Zn})$.

\begin{tabular}{|c|c|c|c|c|c|c|c|c|}
\hline & Rhizon & $\mathrm{H}_{2} \mathrm{O}$ & $\mathrm{NaNO}_{3}$ & $\mathrm{CaCl}_{2}$ & HOAc & $\mathrm{HCl}$ & EDTA & DTPA \\
\hline $\mathrm{Cd}$ & 0.29 & 0.40 & 0.37 & 0.27 & 0.27 & 0.30 & 0.28 & 0.27 \\
\hline $\mathrm{Cu}$ & $0.86^{* *}$ & $0.86^{* *}$ & $0.86^{* *}$ & $0.89^{* *}$ & $0.88^{* *}$ & $0.90^{* *}$ & $0.89^{* *}$ & $0.90^{* *}$ \\
\hline $\mathrm{Ni}$ & $0.72^{* *}$ & $0.95^{* *}$ & $0.95^{* *}$ & $0.95^{* *}$ & $0.95^{* *}$ & $0.96^{* *}$ & $0.96^{* *}$ & $0.96^{* *}$ \\
\hline $\mathrm{Pb}$ & $0.58^{* *}$ & $0.50^{*}$ & $0.52^{*}$ & $0.53^{*}$ & $0.49^{*}$ & $0.49^{*}$ & $0.49^{*}$ & $0.53^{*}$ \\
\hline $\mathrm{Zn}$ & 0.43 & $0.45^{*}$ & $0.61^{* *}$ & $0.67^{* *}$ & $0.58^{* *}$ & $0.56^{*}$ & $0.54^{*}$ & $0.62^{* *}$ \\
\hline
\end{tabular}

** Significant at the 0.01 level, ${ }^{*}$ significant at the 0.05 level.

together in an empirical model to simulate their combined effects on plant uptake. The inclusion of soil $\mathrm{pH}$ and clay content improved the correlations with plant uptake to different extents for different extraction methods, particularly for $\mathrm{Pb}$, for which the extractable amounts by any of the tested extraction methods were not correlated with plant uptake by simple correlation analysis. Our study shows that soil properties should additionally be considered when predicting heavy metal phytoavailability from soil extractions.

\section{Conflict of Interests}

The authors declare that there is no conflict of interests regarding the publication of this paper. 


\section{Acknowledgment}

The authors would like to thank the Ministry of Science and Technology of the Republic of China, Taiwan, for financially supporting this research under Contract no. NSC 96-2622-E020-006-CC3.

\section{References}

[1] U. Förstner, "Metal speciation-general concepts and applications," International Journal of Environmental Analytical Chemistry, vol. 51, no. 1-4, pp. 5-23, 1993.

[2] N. W. Menzies, M. J. Donn, and P. M. Kopittke, "Evaluation of extractants for estimation of the phytoavailable trace metals in soils," Environmental Pollution, vol. 145, no. 1, pp. 121-130, 2007.

[3] A. Kabata-Pendias, "Soil-plant transfer of trace elements-an environmental issue," Geoderma, vol. 122, no. 2-4, pp. 143-149, 2004.

[4] E. Meers, R. Samson, F. M. G. Tack et al., "Phytoavailability assessment of heavy metals in soils by single extractions and accumulation by Phaseolus vulgaris," Environmental and Experimental Botany, vol. 60, no. 3, pp. 385-396, 2007.

[5] M. J. McLaughlin, B. A. Zarcinas, D. P. Stevens, and N. Cook, "Soil testing for heavy metals," Communications in Soil Science and Plant Analysis, vol. 31, no. 11-14, pp. 1661-1700, 2000.

[6] E. Meers, S. Lamsal, P. Vervaeke, M. Hopgood, N. Lust, and F. M. G. Tack, "Availability of heavy metals for uptake by Salix viminalis on a moderately contaminated dredged sediment disposal site," Environmental Pollution, vol. 137, no. 2, pp. 354364, 2005.

[7] V. Séguin, C. Gagnon, and F. Courchesne, "Changes in water extractable metals, $\mathrm{pH}$ and organic carbon concentrations at the soil-root interface of forested soils," Plant and Soil, vol. 260, no. 1-2, pp. 1-17, 2004.

[8] L. Weihermüller, J. Siemens, M. Deurer et al., "In situ soil water extraction: a review," Journal of Environmental Quality, vol. 36, no. 6, pp. 1735-1748, 2007.

[9] I. Novozamsky, T. H. M. Lexmond, and V. J. G. Houba, "A single extraction procedure of soil for evaluation of uptake of some heavy metals by plant," International Journal of Environmental Analytical Chemistry, vol. 51, no. 1-4, pp. 47-58, 1993.

[10] M. Pueyo, J. F. López-Sánchez, and G. Rauret, "Assessment of $\mathrm{CaCl}_{2}, \mathrm{NaNO}_{3}$ and $\mathrm{NH}_{4} \mathrm{NO}_{3}$ extraction procedures for the study of $\mathrm{Cd}, \mathrm{Cu}, \mathrm{Pb}$ and $\mathrm{Zn}$ extractability in contaminated soils," Analytica Chimica Acta, vol. 504, no. 2, pp. 217-226, 2004.

[11] A. Tessier, P. G. C. Campbell, and M. Blsson, "Sequential extraction procedure for the speciation of particulate trace metals," Analytical Chemistry, vol. 51, no. 7, pp. 844-851, 1979.

[12] L. M. Shuman, "Fractionation method for soil microelements.", Soil Science, vol. 140, no. 1, pp. 11-22, 1985.

[13] J. T. Sims and G. V. Johnson, "Micronutrient soil tests," in Micronutrients in Agriculture, J. J. Mortvedt, F. R. Cox, L. M. Shuman, and R. M. Welch, Eds., Soil Science Society of America Book Series, No. 4, pp. 427-476, Soil Science Society of America, Madison, Wis, USA, 2nd edition, 1991.

[14] P. Quevauviller, G. Rauret, H. Muntau et al., "Evaluation of a sequential extraction procedure for the determination of extractable trace metal contents in sediments," Fresenius' Journal of Analytical Chemistry, vol. 349, no. 12, pp. 808-814, 1994.
[15] D. Duan, M. Wang, M. Yu et al., "Does the compositional change of soil organic matter in the rhizosphere and bulk soil of tea plants induced by tea polyphenols correlate with $\mathrm{Pb}$ bioavailability?" Journal of Soils and Sediments, vol. 14, no. 2, pp. 394-406, 2014.

[16] D. E. Baker and M. C. Amacher, "Nickel, copper, zinc and cadmium," in Methods of Soil Analysis, Part 2, A. L. Page, R. H. Millerm, and D. R. Keeney, Eds., Agronomy Monograph 9, pp. 323-336, Agronomy Society of America and Soil Science Society of America, Madison, Wis, USA, 1982.

[17] W. L. Lindsay and W. A. Norvell, "Development of DTPA soil test for Zn, Fe, Mn, Cu," Soil Science Society of America Journal, vol. 42, no. 3, pp. 421-428, 1978.

[18] T. Zhang, H. Wei, X. H. Yang et al., "Influence of the selective EDTA derivative phenyldiaminetetraacetic acid on the speciation and extraction of heavy metals from a contaminated soil," Chemosphere, vol. 109, no. 8, pp. 1-6, 2014.

[19] M. Rajkumar, S. Sandhya, M. N. V. Prasad, and H. Freitas, "Perspectives of plant-associated microbes in heavy metal phytoremediation," Biotechnology Advances, vol. 30, no. 6, pp. 1562-1574, 2012.

[20] X.-P. Wang, X.-Q. Shan, S.-Z. Zhang, and B. Wen, "A model for evaluation of the phytoavailability of trace elements to vegetables under the field conditions," Chemosphere, vol. 55, no. 6, pp. 811-822, 2004.

[21] M. H. Feng, X. Q. Shan, S. Z. Zhang, and B. Wen, "Comparison of a rhizosphere-based method with other one-step extraction methods for assessing the bioavailability of soil metals to wheat," Chemosphere, vol. 59, no. 7, pp. 939-949, 2005.

[22] Y. T. Chang, H. C. Hsi, Z. Y. Hseu, and S. L. Jheng, "Chemical stabilization of cadmium in acidic soil using alkaline agronomic and industrial byproducts," Journal of Environmental Science and Health, Part A: Toxic/Hazardous Substance \& Environmental Engineering, vol. 48, no. 13, pp. 1748-1756, 2013.

[23] A. Obrador, J. M. Alvarez, L. M. Lopez-Valdivia, D. Gonzalez, J. Novillo, and M. I. Rico, "Relationships of soil properties with $\mathrm{Mn}$ and $\mathrm{Zn}$ distribution in acidic soils and their uptake by a barley crop," Geoderma, vol. 137, no. 3-4, pp. 432-443, 2007.

[24] E. O. McLean, "Soil pH and lime requirement," in Methods of Soil Analysis, Part 2, A. L. Page, R. H. Miller, and D. R. Keeney, Eds., Agronomy Monograph 9, pp. 199-224, Agronomy Society of America and Soil Science Society of America, Madison, Wis, USA, 2nd edition, 1982.

[25] D. W. Nelson and L. E. Sommers, "Total carbon, OC, and organic matter," in Methods of Soil Analysis, Part 2, A. L. Page, R. H. Miller, and D. R. Keeney, Eds., pp. 539-577, Agronomy Society of America and Soil Science Society of America, Madison, Wis, USA, 2nd edition, 1982.

[26] J. D. Rhoades, "Cation exchange capacity," in Methods of Soil Analysis, Part 2, A. L. Page, R. H. Miller, and D. R. Keeney, Eds., vol. 9 of Agronomy Monograph, pp. 149-157, Agronomy Society of America and Soil Science Society of America, Madison, Wis, USA, 2nd edition, 1982.

[27] J. D. Rhoades, "Soluble salts," in Methods of Soil Analysis, Part 2, A. L. Page, R. H. Miller, and D. R. Keeney, Eds., Agronomy Monograph 9, pp. 167-180, Agronomy Society of America and Soil Science Society of America, Madison, Wis, USA, 2nd edition, 1982.

[28] O. P. Mehra and M. L. Jackson, "Iron oxides removed from soils and clays by a dithionite-citrate system buffered with sodium bicarbonate," Clays and Clay Minerals, vol. 7, no. 3, pp. 317-327, 1960. 
[29] J. A. McKeague and J. H. Day, "Dithionite and oxalate extractable $\mathrm{Fe}$ and $\mathrm{Al}$ as acids in different various classes of soils," Canadian Journal of Soil Science, vol. 46, no. 1, pp. 13-22, 1966.

[30] G. W. Gee and J. W. Bauder, "Particle-size analysis," in Methods of Soil Analysis, Part 1, A. Klute, Ed., vol. 9 of Agronomy Monograph, pp. 383-411, Agronomy Society of America and Soil Science Society of America, Madison, Wis, USA, 2nd edition, 1986.

[31] International Organization for Standardization (ISO), "Soil quality: extraction of trace elements soluble in aqua-regia," ISO 11466, ISO, Geneva, Switzerland, 1995.

[32] Z. Hseu, "Evaluating heavy metal contents in nine composts using four digestion methods," Bioresource Technology, vol. 95, no. 1, pp. 53-59, 2004.

[33] C. Whalley and A. Grant, "Assessment of the phase selectivity of the European Community Bureau of Reference (BCR) sequential extraction procedure for metals in sediment," Analytica Chimica Acta, vol. 291, no. 3, pp. 287-295, 1994.

[34] M. J. Mench, V. L. Didier, M. Loffler, A. Gomez, and P. Masson, "A mimicked in-situ remediation study of metal-contaminated soils with emphasis on cadmium and lead," Journal of Environmental Quality, vol. 23, no. 1, pp. 58-63, 1994.

[35] S. K. Gupta and C. Aten, "Comparison and evaluation of extraction media and their suitability in a simple model to predict the biological relevance of heavy metal concentrations in contaminated soils," International Journal of Environmental Analytical Chemistry, vol. 51, no. 1-4, pp. 25-46, 1993.

[36] A. M. Ure, P. Quevauviller, H. Muntau, and B. Griepinck, "Speciation of heavy metals in soils and sediments: an account of the improvement and harmonization of extraction techniques undertaken under the auspices of the BCR of the commission of the European communities," International Journal of Environmental Analytical Chemistry, vol. 51, no. 1-4, pp. 135-151, 1993.

[37] J. I. Wear and C. E. Evans, "Relationship of zinc uptake by corn and sorghum to soil zinc measured by three extractants," Soil Science Society of America Proceedings, vol. 32, no. 4, pp. 543$546,1968$. 

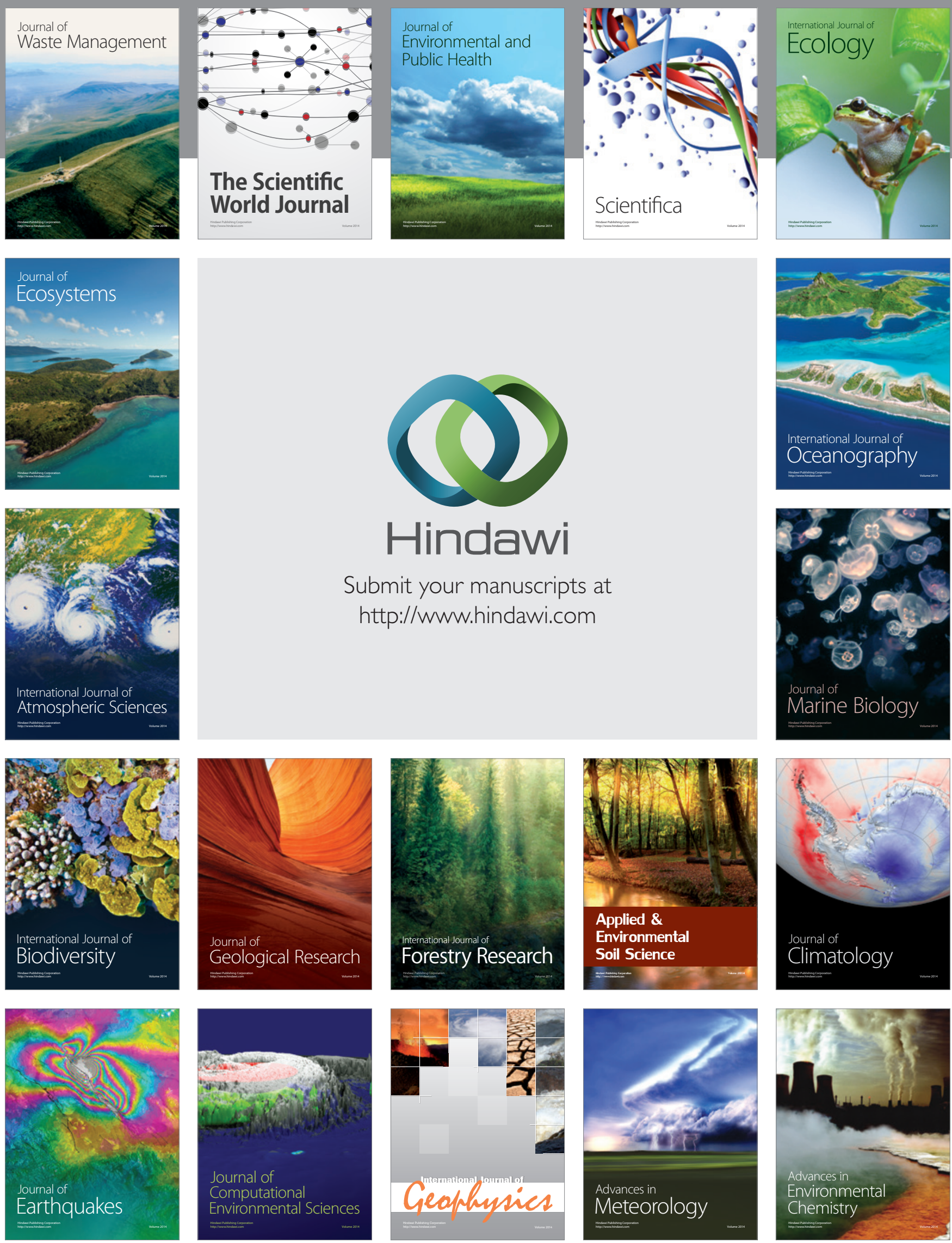